\title{
PENGARUH PENGAMPUNAN PAJAK DAN KEMUDAHAN ADMINISTRASI PAJAK TERHADAP KEPATUHAN WAJIB PAJAK ORANG PRIBADI PADA KPP PRATAMA JAKARTA PENJARINGAN
}

\author{
M. Anjar Nurul Hayat ${ }^{1}$, Rudi Kristanto ${ }^{2}$ \\ Institut Ilmu Sosial dan Manajemen STIAMI \\ Email:anjar.hayat@gmail.com,rudi.kristanto@stiami.ac.id
}

\begin{tabular}{|c|c|}
\hline ARTIKEL INFO & ABSTRACT \\
\hline $\begin{array}{l}\text { Keywords; } \text { Tax Amnesty, Ease } \\
\text { of Tax Administration, } \\
\text { Taxpayer Compliance }\end{array}$ & $\begin{array}{l}\text { The purpose of this study is to determine the implementation of tax } \\
\text { pardons conducted by KPP Pratama Jakarta Penjaringan, ease of tax } \\
\text { administration and changes in taxpayer compliance increase. The conclusion } \\
\text { of research, that the implementation of tax amnesty and the ease of tax } \\
\text { administration conducted by KPP Penjaringan in the period 2015-2017 have } \\
\text { a strong influence on taxpayer compliance. The coefficient of determination } \\
\text { (adjusted R2) shows the variable of Tax Amnesty (X1) and Ease of Tax } \\
\text { Administration (X2) can explain or explain Personal Taxpayer Compliance } \\
\text { KPP Pratama Jakarta Penjaringan (Y) of } 28 \% \text { KPP is advised to improve } \\
\text { tax administration system, service to Taxpayer, tax law enforcement and tax } \\
\text { rate and intensive socialization to taxpayer about good tax administration } \\
\text { knowledge. }\end{array}$ \\
\hline
\end{tabular}

\section{PENDAHULUAN}

Pertumbuhan ekonomi nasional dalam beberapa tahun terakhir cenderung mengalami perlambatan yang berdampak pada turunnya penerimaan pajak dan juga telah mengurangi ketersediaan likuiditas dalam negeri yang sangat diperlukan untuk meningkatkan pertumbuhan ekonomi Indonesia. Di sisi lain, banyak Harta warga negara Indonesia yang ditempatkan di luar wilayah Negara Kesatuan Republik Indonesia (NKRI), baik dalam bentuk likuid maupun nonlikuid, yang seharusnya dapat dimanfaatkan untuk menambah likuiditas dalam negeri yang dapat mendorong pertumbuhan ekonomi nasional.

Pada tahun 1984 Indonesia mencatat Sejarah Tax Amnesty. Tetapi, bukan untuk mengembalikan dana revolusi, melainkan untuk mengubah sistem perpajakan di Indonesia dari official-assesment (besarnya jumlah pajak ditentukan oleh pemerintah) diubah ke self-assesment (besarnya pajak ditentukan oleh wajib pajak sendiri). Tax Amnesty di Indonesia tahun 1984 ini mengalami kegagalan karena memang sistem perpajakan belum terbangun. Kita berharap, Tax Amnesty tahun 2016 ini akan sukses dan memajukan perekonomian Indonesia.

Tax Amnesty atau pengampunan pajak adalah program kebijakan pemerintah yang memberikan kesempatan kepada Wajib Pajak untuk melunasi tunggakan pajaknya tanpa adanya sanksi administrasi guna meningkatkan kepatuhan Wajib Pajak dan penerimaan negara (Sawyer, 2006: 2). Pengampunan Pajak dilakukan dalam bentuk pelepasan hak negara untuk menagih pajak yang seharusnya terutang. Oleh karena itu, sudah sewajarnya jika Wajib Pajak diwajibkan untuk membayar Uang Tebusan atas Pengampunan Pajak yang diperolehnya. Dalam rangka pelaksanaan Undang-Undang ini, penerimaan Uang Tebusan diperlakukan sebagai penerimaan Pajak Penghasilan dalam Anggaran Pendapatan dan Belanja Negara.

Disamping Pengampunan Pajak (Tax Amnesty), kepatuhan Wajib Pajak juga perlu ditumbuhkan melalui peningkatan kemudahan administrasi pajak, karena sebagus apapun pengampunan pajak, jika tidak disertai dengan kemudahan administrasi pajak itu sendiri, maka kepatuhan wajib pajak akan menjadi terkendala. Masih rendahnya kepatuhan masyarakat dalam membayar pajak ini seringkali disebabkan oleh karena ketidaktahuan masyarakat akan aturan perpajakan. Beberapa pendapat dikemukakan mengenai faktor penghambat yang menyebabkan rendahnya kepatuhan masyarakat terhadap kewajiban perpajakan adalah faktor lingkungan. Faktor lingkungan merupakan faktor 
yang berada diluar kendali Wajib Pajak. Faktor lingkungan akan memberikan pengaruh terhadap sikap Wajib Pajak dalam melaksanakan kewajibannya. Faktor lingkungan meliputi undang undang dan peraturan pajak (tax law), kebijakan pajak (tax policy) dan kemudahan administrasi pajak (tax administration).

Menurut Satriyo (2007), kemudahan administrasi pajak dalam arti sempit merupakan penatausahaan dan pelayanan atas hak-hak dan kewajiban-kewajiban kemudahan pembayaran pajak, baik penatausahaan dan pelayanan yang dilakukan di kantor pajak maupun ditempat wajib pajak, sedangkan administrasi pajak dalam arti luas meliputi fungsi, sistem dan organisasi atau kelembagaan. Sebagai suatu fungsi, administrasi perpajakan meliputi perencanaan, pengorganisasian, penggerakan dan pengendalian perpajakan. Kemudahan administrasi pajak dilihat dari segi kemudahan dalam melakukan pembayaran pajak, kemudahan mengetahui data pembayaran dan tunggakan pajak, kemudahan dalam pemeriksaan pajak keakuratan dan kemudahan dalam pelaporan SPT (Surat Pemberitahuan).

Fenomenanya adalah tingkat kepatuhan Wajib Pajak di KPP Pratama Jakarta Penjaringan yang cenderung menurun yang dilihat dari tahun 2015 - 2016. Berikut data SPT yang masuk di KPP Pratama Jakarta Penjaringan, yang mengindikasikan tingkat kepatuhan Wajib Pajak.

Tabel 1. Jumlah SPT yang Masuk di KPP Pratama Jakarta Penjaringan Tahun 2016-2017

\begin{tabular}{cccc}
\hline Tahun & WP Terdaftar & Lapor SPT & Persentase \\
\hline 2015 & 55.539 & 23.544 & $42.39 \%$ \\
2016 & 62.107 & 24.252 & $39.05 \%$ \\
\hline
\end{tabular}

Penelitian yang dilakukan oleh Kadek Diah Puspareni, I Gusti Ayu Purnawati dan Made Arie Wahyuni (2017) menunjukkan tax amnesty berpengaruh positif terhadap kepatuhan Wajib Pajak Orang Pribadi. Muhammad Yusril, Siti Ragil Handayani dan Nila Firdausi Nuzula (2016) menyimpulkan bahwa kemudahan administrasi perpajakan berpengaruh positif dan signifikan terhadap kepatuhan Wajib Pajak.

Dari uraian latar belakang dan identifikasi masalah di atas, penulis membatasi masalah dalam penelitian ini hanya kepada pelaksanaan pengampunan pajak dan kemudahan administrasi pajak dalam rangka meningkatkan kepatuhan Wajib Pajak Orang Pribadi pada KPP Pratama Jakarta Penjaringan. Adapun yang menjadi perumusan masalah dalam penelitian ini adalah: 1). Seberapa besar pengaruh pelaksanaan pengampunan Wajib Pajak yang dilakukan oleh KPP Pratama Jakarta Penjaringan terhadap Kepatuhan Wajib Pajak?, 2). Seberapa besar pengaruh kemudahan administrasi pajak terhadap kepatuhan Wajib Pajak di KPP Pratama Jakarta Penjaringan?, dan 3). Seberapa besar pengaruh pengampunan Wajib Pajak dan kemudahan administrasi pajak terhadap kepatuhan Wajib Pajak pada KPP Pratama Jakarta Penjaringan?

\section{LANDASAN TEORI}

Kajian literatur dalam penelitian ini merupakan landasan teoritis dari penelitian yang dapat memberikan landasan teori-teori yang dibutuhkan dalam penelitian, meliputi: pengampunan pajak, kemudahan administrasi pajak, dan kepatuhan wajib pajak.

Teori yang digunakan adalah teori pengampunan pajak yang antara lain dikemukakan oleh Sawyer (2006), James (2015), Devano dan Rahayu (2006), Zainal Muttaqin (2012), serta para pakar lainnya. Adapun teori kemudahan administrasi pajak dikemukakan oleh Hardika (2006), Satriyo (2007), Pandiangan (2008), Carlos A. Silvani dan Melisari (2008) serta pakar-pakar yang lainnya.

Selanjutnya teori kepatuhan wajib pajak dikemukakan oleh Safri Nurmantu dalam Rahayu (2010), Norman D. Nowak yang dikutip oleh Siti Kurnia Rahayu (2010), Prof. Paul Webley (OECD, 2004), Nasucha (2006), Machfud Sidik yang dikutip oleh Siti Kurnia Rahayu (2010) dan pendapat dari pakar lainnya.

Definisi pajak menurut. Adriani adalah sebagai berikut :

"Pajak ialah iuran masyarakat kepada negara (yang dapat dipaksakan) yang terutang oleh wajib pajak yang membayarnya menurut peraturan-peraturan umum (Undang-Undang) dengan tidak 
mendapat prestasi kembali yang langsung dapat ditunjuk dan yang gunanya adalah untuk membiayai pengeluaran-pengeluaran umum \ berhubungan tugas negara untuk menyelenggarakan pemerintah." (dikutip dari buku Mohamad Zain. 2008. Manajemen Pajak)

Sedangkan menurut Soemitro, pajak adalah "Iuran rakyat kepada kas negara berdasarkan Undang-Undang (yang dapat dipaksakan) dengan tiada mendapat jasa timbal (kontra prestasi) yang langsung dapat ditunjukan dan yang digunakan untuk membayar pengeluaran umum.”.

Pajak memiliki fungsi dalam meningkatkan kesejahteraan umum. Secara general lebih dikenal dengan dua macam fungsi pajak, yaitu fungsi budgetair dan fungsi regular (Soemarso, 2007:3): 1). Fungsi penerimaan (budgetair), merupakan fungsi utama pajak, atau fungsi fiskal (fiscal function), adalah suatu fungsi dimana pajak digunakan sebagai alat untuk memasukan dana secara optimal ke kas negara berdasarkan undang - undang perpajakan yang berlaku, dan 2). Fungsi mengatur (reguler), merupakan sebagai alat untuk mengatur atau melaksanakan kebijakan-kebijakan di bidang sosial dan ekonomi, politik, dan tujuan tertentu. Disamping usaha untuk memasukan uang untuk kegunaan kas negara, pajak dimaksudkan pula sebagai usaha pemerintah untuk ikut andil dalam hal mengatur dan bilamana perlu mengubah susunan pendapatan dan kekayaan dalam sektor swasta atau di luar bidang bidang keuangan lainnya.

Berdasarkan teori Adam Smith yang dikutip oleh Waluyo (2007:6), pemungutan pajak didasarkan pada empat asas, yaitu: 1). Equity atau Equality, keadilan adalah pertimbangan penting dalam membangun sistem perpajakan. Pemungutan pajak hendaknya dilakukan seimbang dengan kemampuannya. Negara tidak boleh melakukan diskriminasi diantara sesama pembayar pajak, 2). Certainty, diartikan pajak yang harus dibayar haruslah terang (certain) dan tidak mengenal kompromis (not arbitrary). Kepastian hukum harus tercermin mengenai subyek, obyek, besarnya pajak dan juga ketentuan mengenai pembayaran, 3). Convenience, Dipungutnya pajak pada saat yang paling baik bagi pembayar pajak, yaitu saat diterimanya penghasilan, dan 4). Economy, pemungutan pajak hendaknya dilakukan sehemat-hematnya. Biaya pemungutan hendaknya tidak melebihi pemasukan pajaknya.

Dan berdasarkan Siti Resmi (2008:7), pengelompokan pajak dapat dilakukan menurut golongan, wewenang pemungut, maupun sifatnya, dapat dijelaskan sebagai berikut:

Berdasarkan golongan pajak dapat dikelompokan menjadi dua: 1). Pajak langsung, yaitu pajak yang bebannya harus ditanggung sendiri oleh Wajib Pajak yang bersangkutan dan tidak dapat dialihkan kepada pihak lain. Contoh: Pajak Penghasilan (PPh), 2). Pajak tidak langsung, yaitu pajak yang bebannya dapat dialihkan atau digeserkan kepada pihak lain. Contoh: Pajak Tambahan Nilai (PPN) dan Pajak Penjualan atas Barang Mewah (PPnBM).

Berdasarkan wewenang pemungutannya, pajak dapat dibagi menjadi dua yaitu: 1). Pajak Pusat atau Pajak Negara, yaitu pajak yang wewenang pemungutannya ada pada Pemerintah Pusat yang pelaksanaannya dilakukan oleh Departemen Keuangan melalui Direktorat Jendaral Pajak dan digunakan untuk membiayai rumah tangga Negara pada umumnya., 2). Pajak Daerah, yang wewenang pemungutannya ada pada Pemerintah yang pelaksanaanya dilakukan oleh Dinas Pendapatan Daerah dan digunakan untuk membiayai rumah tangga daerah masing-masing. Pajak Daerah diatur dalam Undang-Undang dan hasilnya akan masuk ke APBD. Contoh: Pajak Bahan Bakar Kendaraan Bermotor, Pajak Hotel, Pajak Restoran, dan sebagainya.

Berdasarkan sifatnya, pajak dibedakan menjadi dua yaitu: 1). Pajak subjektif, yaitu pajak yang memperhatikan kondisi atau keadaan Wajib Pajak. Dalam menentukan pajaknya harus ada alasanalasan objektif yang berhubungan erat dengan keadaan materialnya, yaitu Gaya Pikul. Gaya Pikul adalah kemampuan Wajib Pajak setelah dikurangi biaya hidup minimum, 2). Pajak objektif, yaitu pajak yang pada awalnya memperhatikan objek yang menyebabkan timbulnya kewajiban membayar, kemudian baru dicari subjeknya baik orang pribadi maupun badan. Jadi dengan kata lain pajak objektif adalah pengenaan pajak yang hanya memperhatikan kondisi saja.

\section{Pengampunan Pajak}

Menurut Sawyer (2006:2) pengampunan pajak atau Tax Amnesty yaitu sebuah program kebijakan pemerintah yang memberikan kesempatan kepada Wajib Pajak untuk melunasi tunggakan pajaknya tanpa adanya sanksi administrasi guna meningkatkan kepatuhan Wajib Pajak dan penerimaan negara. Tax Amnesty diharapkan akan mendorong peningkatan kepatuhan sukarela Wajib Pajak dimasa yang akan datang. Pengampunan pajak diharapkan menghasilkan penerimaan pajak yang selama ini 
belum atau kurang dibayar, di samping meningkatkan kepatuhan membayar pajak karena semakin efektifnya pengawasan dan semakin akuratnya informasi mengenai daftar kekayaan Wajib Pajak.

Progra Tax Amnesty bertujuan untuk: 1). 1. Mempercepat restrukturisasi ekonomi dan pertumbuhan melalui pengalihan harta, dan akan berdampak terhadap peningkatan likuiditas domestik, perbaikan nilai tukar Rupiah, penurunan suku bunga, dan peningkatan investasi, 2). Mendorong reformasi perpajakan agar sistem perpajakan yang lebih berkeadilan serta perluasan basis data perpajakan yang lebih valid, komprehensif, dan terintegrasi, dan 3). Meningkatkan penerimaan pajak, yang akan digunakan untuk pembiayaan pembangunan.

Menuurut pendapat Erwin Silitonga, dalam literatur sekurang-kurangnya terdapat 4 jenis pengampunan pajak, jenis yang dimaksud adalah sebagai berikut : 1). Pengampunan yang dapat diberikan terhadap sanksi pidana perpajakan saja sedangkan kewajiban untuk membayar pokok pajak termasuk pengenaan sanksi administrasi seperti bunga dan denda tetap ada. Tujuan dari pengampunan ini yaitu memungut dan menagih utang pajak tahun-tahun sebelumnya yang tidak dibayar atau dibayar tidak sesuai dengan peraturan perundang - undangan, sehingga penerimaan negara meningkat sekaligus jumlah wajib pajak bertambah, 2). Pengampunan pajak yang diberikan tidak hanya berupa penghapusan sanksi pidana, tetapi juga sanksi administrasi berupa denda. Tujuan dari pengampunan ini adalah dasarnya sama dengan jenis 1 (pertama), yang berbeda adalah jenis sanksi administrasi yang dikenakan oleh fiskus hanya sebatas bunga atas kekurangan pajak. Dengan demikian, model ini tetap harus membayar pokok pajak ditambah dengan bunga atas kekurangan pokok tersebut, 3). Pengampunan pajak diberikan atas seluruh sanksi, baik sanksi administrasi maupun sanksi pidana. Konsekuensi dari pengampunan jenis ini adalah wajib pajak hanya dikenakan kewajiban sebatas melunasi utang pokok untuk tahun-tahun sebelumnya tanpa dikenakan pidana, dan 4). Pengampunan diberikan terhadap seluruh utang pajak untuk tahun-tahun sebelumnya dan juga atas seluruh sanksi baik yang bersifat administratif maupun pidana. Dalam pengampunan pajak jenis ini, negara melepaskan hak untuk melakukan penagihan atas seluruh hutang pajak yang harus dibayar.

\section{Kemudahan Administrasi Pajak}

Menurut Hardika (2006), terdapat tiga kemudahan kemudahan dalam administrasi perpajakan, yaitu: 1). Dimana instansi atau badan yang mempunyai wewenang dan tanggung jawab untuk menyelenggarakan kemudahan pemungutan pajak, 2). Dimana orang-orang yang terdiri dari pejabat dan pegawai yang bekerja pada instansi perpajakan yang secara nyata melaksanakan kegiatan kemudahan pemungutan perpajakan, dan 3). Pada proses kegiatan penyelenggaraan kemudahan pemungutan pajak yang ditata laksanakan sedemikian rupa sehingga dapat mencapai sasaran yang telah digariskan dalam kebijakan kemudahan perpajakan, berdasarkan sarana hukum yang ditemukan oleh undang-undang pajak yang efisien.

Suatu Kemudahan administrasi perpajakan dikatakan efektif apabila mampu mengatasi masalah-masalah berikut: Wajib Pajak yang tidak terdaftar (unregistered taxpayers), Wajib Pajak yang tidak menyampaikan Surat Pemberitahuan (stopfiling taxpayers), Penyelundup pajak (tax evaders), Penunggak pajak (delinquent taxpayers), Carlos A. Silvani dalam Melisari (2008) yaitu : 1). Wajib Pajak yang tidak terdaftar (unregistered taxpayers), sejauh mana administrasi pajak mampu mendeteksi dan mengambil tindakan terhadap masyarakat yang belum terdaftar sebagai wajib pajak walaupun seharusnya yang bersangkutan sudah memenuhi ketentuan untuk menjadi wajib pajak, 2). Wajib Pajak yang tidak menyampaikan Surat Pemberitahuan (stopfiling taxpayers), yaitu wajib pajak yang sudah terdaftar di administrasi kantor pajak, tetapi tidak menyampaikan Surat Pemberitahuan. Administrasi pajak dituntut untuk dapat mengumpulkan data sekaligus menindaklanjutinya dengan meminimalkan kasus, 3). Penyelundup pajak (tax evaders), yaitu wajib pajak yang melaporkan pajak lebih kecil dari yang seharusnya menurut ketentuan perundang-undangan perpajakan. Sistem self assessment yang sekarang berlaku memang rentan menyebabkan terjadinya modus kejahatan seperti ini, karena sangat tergantung dari kejujuran wajib pajak, dan 4). Penunggak pajak (delinquent taxpayers), dari tahun ke tahun selalu ada tunggakan pajak yang terjadi, bahkan menunjukkan kecenderungan yang semakin meningkat. Permasalahan ini seolah sudah menjadi benang kusut yang selalu dihadapi oleh otoritas pajak setiap tahunnya. 


\section{Kepatuhan Wajib Pajak}

Kepatuhan perpajakan dapat didefinisikan sebagai suatu keadaan dimana Wajib Pajak memenuhi semua kewajiban perpajakan dan melaksanakan hak perpajakannya, Menurut Safri Nurmantu (2005:148) dijelaskan terdapat 2 (dua) macam kepatuhan yaitu: 1). Kepatuhan Formal, yaitu, suatu keadaan dimana Wajib Pajak memenuhi kewajiban perpajakannya secara formal sesuai dengan ketentuan dalam Undang-Undang perpajakan. Dalam hal ini kepatuhan memenuhi: a). Wajib pajak membayar pajak dengan tepat waktu, b). Wajib pajak membayar dengan tepat jumlah, dan c). Wajib pajak tidak memiliki tanggungan Pajak Bumi dan Bangunan, 2). Kepatuhan Material, yaitu dimana suatu keadaan dimana wajib pajak secara substansi atau hakakat memenuhi semua ketentuan perpajakan, sesuai dengan isi dan jiwa Undang-Undang perpajakan. Dalam hal ini kepatuhan memenuhi : a). Wajib Pajak bersedia melaporkan informasi tentang pajak apabila petugas membutuhkan informasi, dan b). Wajib pajak bersifat kooperatif (tidak menyusahkan) petugas pajak dalam pelaksanaan proses administrasi perpajakan, wajib pajak berkeyakinan bahwa melaksanakan kewajiban perpajakan merupakan tindakan sebagai warga negara yang baik.

\section{Penelitian Terdahulu}

Penelitian ini yang dilakukan oleh Kadek Diah Puspareni, I Gusti Ayu Purnawati, dan Made Arie Wahyuni (S1 Ak Universitas Pendidikan Ganesha Singaraja, 2017) dengan menggunakan pendekatan kuantitatif. Hasil penelitian menyimpulkan bahwa pelaksanaan Tax Amnesty yang dilakukan oleh petugas KPP Pratama Wilayah Singaraja sudah sesuai dengan prosedur dan tata cara yang ditentukan dalam peraturan perundang-undangan yang berlaku.

Gambar 1. Model Penelitian

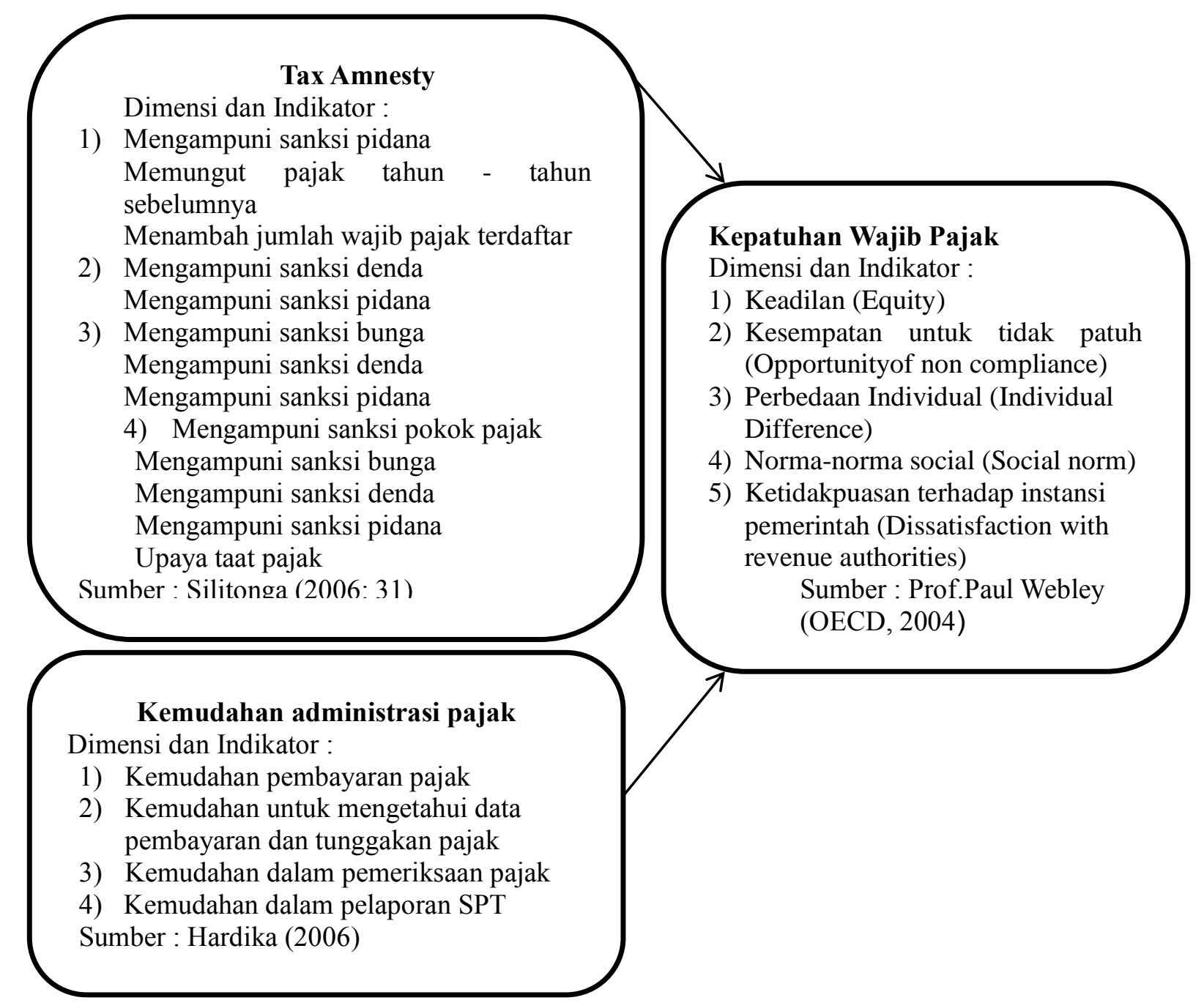




\section{METODOLOGI PENELITAN}

Dalam penelitian ini adalah pendekatan yang digunakan kuantitatif, yaitu penelitian yang menekankan analisisnya pada data numerical atau angka yang diperoleh dengan metode statistik serta dilakukan pada penelitian inferensial atau dalam rangka pengujian hipotesis sehingga diperoleh signifikansi hubungan antara variabel yang diteliti.

Pada Variabel Tax Amnesti (X1) dan Kemudahan administrasi pajak (X2) sebagai variabel yang mempengaruhi atau disebut juga sebagai variabel penyebab, atau sering disebut sebagai variabel bebas atau independent variable (X), serta Variabel kepatuhan Wajib Pajak (Y) sebagai variabel akibat disebut variabel tergantung atau dependent variable.

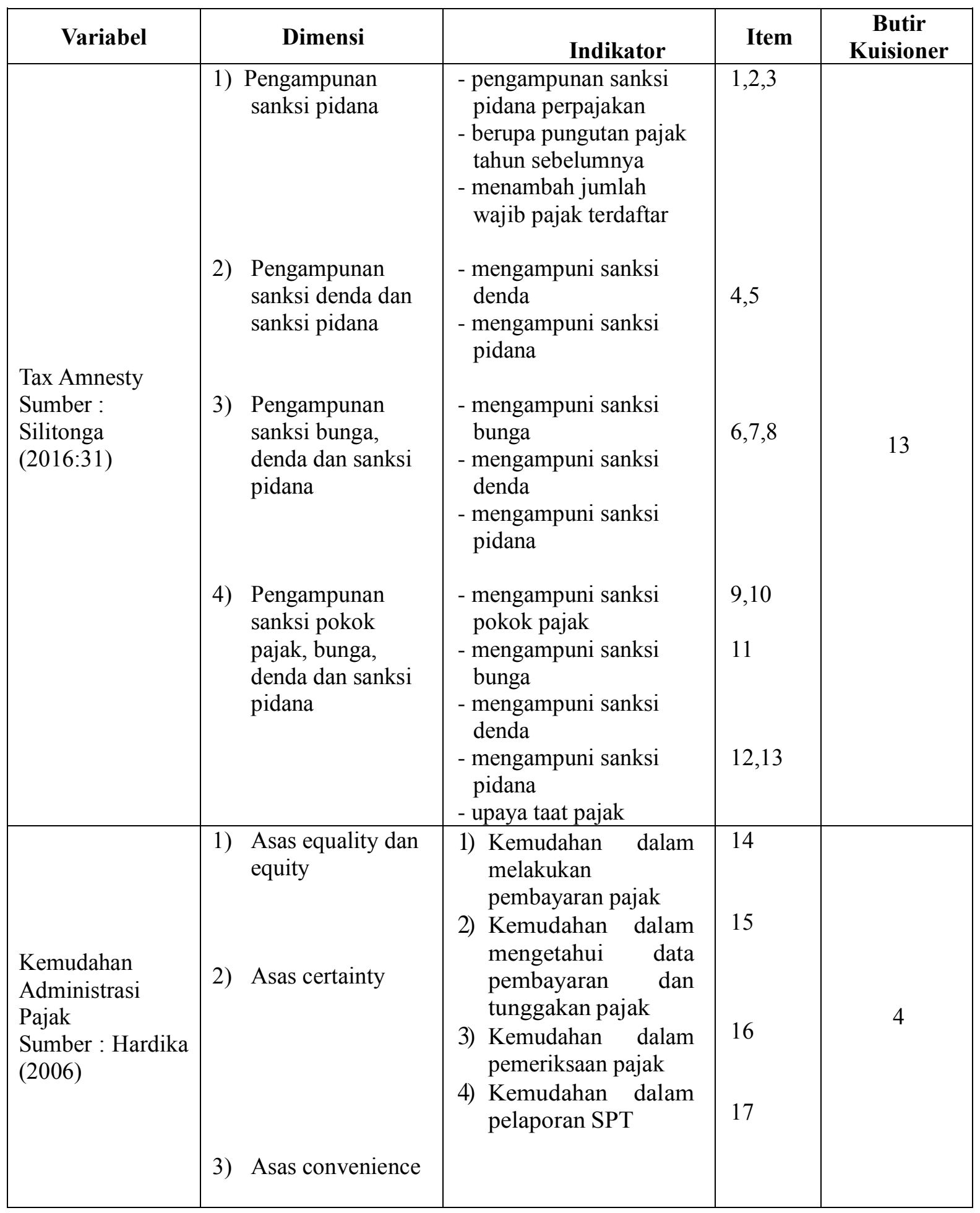




\begin{tabular}{|c|c|c|c|c|}
\hline & 4) Asas efficiency & & & \\
\hline $\begin{array}{l}\text { Kepatuhan Wajib } \\
\text { Pajak } \\
\text { Sumber : } \\
\text { Prof.Paul Webley } \\
\text { (OECD, 2004) }\end{array}$ & $\begin{array}{ll}\text { 1. } & \text { Keadilan } \\
\text { 2. } & \text { Kesempatan } \\
\text { untuk tidak patuh }\end{array}$ & $\begin{array}{l}\text { - Mendaftarkan diri untuk } \\
\text { NPWP. } \\
\text { - Menyampaikan SPT } \\
\text { dengan tepat waktu. } \\
\text { - Membayar pajak } \\
\text { dengan tepat waktu. } \\
\text { - Bebas dari tindakan } \\
\text { pidana dibidang } \\
\text { perpajakan. } \\
\text { - Bebas dari tunggakan } \\
\text { pajak pada semua jenis } \\
\text { pajak } \\
\text { - Melaporkan kewajiban } \\
\text { pajak dengan jujur } \\
\text { - Mengisi SPT dengan } \\
\text { lengkap dan jelas } \\
\text { - Membayar pajak } \\
\text { dengan jumlah yang } \\
\text { benar } \\
\text { - Melaporkan informasi } \\
\text { tentang pajak jika } \\
\text { petugas pajak } \\
\text { membutuhkan } \\
\text { informasi }\end{array}$ & $\begin{array}{l}18 \\
19 \\
20 \\
21 \\
22 \\
23 \\
24 \\
25\end{array}$ & 9 \\
\hline
\end{tabular}

Pendekatan survei yaitu penelitian yang mengambil sampel dari satu populasi dan menggunakan kuesioner sebagai alat pengumpulan data yang pokok (Singarimbun, 1995:3).

Sampel dalam penelitian ini adalah menggunakan metode quota sampling, yaitu dengan cara menetapkan jumlah tertentu sebagai target yang harus dipenuhi dalam pengambilan sampel dari populasi, kemudian dengan patokan jumlah tersebut peneliti mengambil sampel secara sembarang asal memenuhi persyaratan sebagai sampel dari populasi tersebut.

Pada penelitian ini, persyaratan sebagai sampel dari populasi adalah Wajib Pajak / WP Orang Pribadi yang telah melakukan pengampunan pajak / tax amnesty, peneliti menetapkan 60 orang sebagai sampel penelitian. Sumber data terbagi menjadi dua yaitu data primer dan data sekunder. Dan dalam penelitian ini metode pengumpulan data dilakukan dengan melalui kuisioner dan dokumentasi.

\section{Uji Kualitas Data}

Analisa hasilnya menggunakan program Statistical Package for Sosial Science (SPSS) for Windows Release 24. sebagai berikut :

a. Uji Validitas, validitas alat ukur bertujuan untuk mengetahui sejauhmana skala yang digunakan mampu menghasilkan data yang akurat sesuai tujuan ukurnya.

b. Uji Reliabilitas, disamping melakukan uji validitas, selanjutnya harus pula dilakukan uji reliabilitas yang digunakan untuk mengukur suatu kuesioner yang merupakan indikator dari variabel. Dalam penelitian ini kuesioner dikatakan reliabel jika jawaban seseorang terhadap kuesioner stabil dari waktu ke waktu

\section{Uji Persyaratan Analisis (Asumsi Klasik)}

Yang dilakukan adalah uji persyaratan analisis meliputi: Uji Normalitas, Uji Multikolinieritas, dan Uji Heterokedastisitas.

a. Uji Normalitas, digunakan apakah dalam sebuah model regresi, variabel independent, variabel dependent, atau keduanya mempunyai distribusi normal atau tidak. Model regresi yang baik adalah distribusi normal atau mendekati normal. Uji normalitas pada penelitian ini diuji dengan uji Kolmogorov-Smirnov atau Uji K-S. 
b. Uji Multikolinearitas, bertujuan untuk menguji apakah pada model regresi ditemukan adanya korelasi antar variabel independent. Jika terjadi korelasi, maka dinamakan terdapat problem multikolinearitas. Model regresi yang baik seharusnya tidak terjadi korelasi di antara variabel independent.

c. Uji Heteroskedastisitas, dimaksudkan apakah dalam model regresi terjadi ketidaksamaan variance dari residual satu pengamatan ke pengamatan yang lain. Jika variance dari residual suatu pengamatan ke pengamatan yang tetap, maka disebut Homoskedastisitas dan jika berbeda disebut Heteroskedastisitas, karena data ini menghimpun data yang mewakili berbagai ukuran (kecil, sedang, dan besar).

d. Uji Linieritas, untuk mengetahui apakah dua variabel mempunyai hubungan yang linear atau tidak secara signifikan. Uji ini biasanya digunakan sebagai prasyarat dalam analisis korelasi atau regresi linier. Pada penelitian ini, uji linieritas ditinjau dari nilai F pada ANOVA dari setiap pasangan variabel untuk komponen linier dan nonlinier.

\section{Teknik Analisis Data}

\section{Analisis Regresi Linear Berganda}

Tujuan digunakannya analisis regresi linier berganda ini adalah untuk mengetahui apakah variabel bebas secara bersama-sama mempengaruhi variabel terikat.

$\mathrm{Y}=\mathrm{b}_{1} \mathrm{X}_{1}+\mathrm{b}_{2} \mathrm{X}_{2}+\mathrm{e}$

Dimana :

$\mathrm{Y}=$ Kepatuhan wajib pajak

$\mathrm{b} 1=$ Koefisien regresi pengampunan pajak

b2 = Koefisien regresi kemudahan administrasi pajak

$\mathrm{X} 1=$ Pengampunan pajak

$\mathrm{X} 2=$ Kemudahan administrasi pajak

$\mathrm{e}=$ Varians pengganggu

\section{Pengujian Hipotesis Penelitian}

\section{Uji Secara Parsial (Uji t)}

Untuk mengetahui signifikan atau tidaknya pengaruh antara variabel $\mathrm{X}$ dan variabel $\mathrm{Y}$, maka pengujian hipotesa dilakukan dengan menggunakan rumus uji t menurut Sofar Silaen dan Widiyono (2013:225), sebagai berikut:

$\mathrm{t}_{\text {hitung }} \mathrm{r}=\frac{\sqrt{\mathrm{n}-2}}{\sqrt{1-\mathrm{r}^{2}}}$

Keterangan:

$\mathrm{t}=$ Skor signifikan koefisien korelasi

$\mathrm{r}=$ Koefisien korelasi

$\mathrm{n}=$ Jumlah sampel

$\mathrm{n}-2=$ Derajat bebas

Pengambilan keputusan untuk dilakukan Uji Hipotesis dilakukan dengan cara membandingkan statistik hitung $\left(\mathrm{t}_{\text {hitung }}\right)$ dengan statistik tabel $\left(\mathrm{t}_{\text {tabel }}\right)$, bila:

$\mathrm{t}_{\text {hitung }<\text { tabel }}=\mathrm{H} 0$ Diterima dan Ha ditolak

$\mathrm{t}_{\text {hitung }>\text { tabel }} \quad=\mathrm{H} 0$ Ditolak dan Ha diterima

\section{Uji Secara Simultan (Uji f)}

Menurut Ghozali (2011:98) pengujian ini bertujuan untuk membuktikan apabila variabelvariabel independent $(\mathrm{X})$ secara simultan (bersama-sama) mempunyai pengaruh terhadap variabel dependent (Y). Apabila ${ }^{\mathrm{f}}$ hitung $>{ }^{\mathrm{f}}$ tabel maka $\mathrm{H}_{\mathrm{o}}$ di tolak dan $\mathrm{H}_{\mathrm{a}}$ diterima, yang berarti variabel independent mempunyai pengaruh yang signifikan terhadap variabel dependent dengan menggunakan tingkat signifikan sebesar 5\% jika nilai ${ }^{\mathrm{f}}$ hitung $>{ }^{\mathrm{f}}$ tabel maka secara bersama-sama seluruh variabel independent mempengaruhi variabel dependent. 


\section{Korelasi Product Moment}

Korelasi Product Moment merupakan suatu Teknik korelasi yang digunakan untuk mencari hubungan dan membuktikan hipotesis hubungan dua variabel bila data kedua variabel berbentuk interval atau ratio, dan sumber data dari dua variabel atau lebih tersebut adalah sama (Sugiyono:2009).

Berikut ini dikemukakan rumus yang paling sederhana yang dapat digunakan untuk menghitung koefesien korelasi adalah sebagai berikut :

$$
r_{x y}=\frac{n \sum x y-\left(\sum x\right)\left(\sum y\right)}{\sqrt{\left.\left(n \sum x^{2}-\left(\sum x\right)^{2}\right)\left(n \sum y^{2}\right)-\left(\sum y\right)^{2}\right)}}
$$

$$
\begin{aligned}
& \text { Dimana : } \\
& \begin{aligned}
\mathrm{rxy} & =\text { Korelasi antara variable } \mathrm{x} \text { dengan } \mathrm{y} \\
\mathrm{x} & =\text { variable } \mathrm{x} \\
\mathrm{x} & =\text { variable } \mathrm{y}
\end{aligned}
\end{aligned}
$$

\section{Koefisien Determinasi}

Koefisien Determinasi $\left(\mathrm{R}^{2}\right)$ digunakan untuk mengukur seberapa jauh kemampuan model dalam menerangkan variasi variabel dependent. Nilai koefisien determinasi ada diantara nol dan satu. Nilai $\mathrm{R}^{2}$ yang kecil berarti kemampuan variabel-variabel independent dalam menjelaskan variasi variabel dependent amat terbatas. Nilai $\mathrm{R}^{2}$ yang mendekati satu berarti variabel-variabel independent memberikan hampir semua informasi yang dibutuhkan untuk memprediksi variasi-variasi dependent (Kuncoro, 2001).

\section{Lokasi dan Jadwal Penelitian}

Tempat penelitian dilakukan Pada dilakukan di KPP Pratama Jakarta Penjaringan. KPP berlokasi di Jl. Lada No. 3, Penjaringan, RT.4/RW.6, Pinangsia, Tamansari, Kota Jakarta Utara.dengan jadwal penelitian dilakukan dari mulai sekitar bulan Oktober 2017 s/d Januari 2017

\section{HASIL PENELITIAN DAN PEMBAHASAN}

Pada pelaksanaannya tugas KPP Pratama Jakarta Penjaringan adalah melaksanakan pelayanan, pengawasan administrasi, dan pemeriksaan terhadap Wajib Pajak di bidang Pajak Penghasilan, Pajak Pertambahan Nilai, Pajak Penjualan atas Barang Mewah, dan Pajak Tidak Langsung lainnya dalam wilayah wewenangnya berdasarkan peraturan perundang-undangan perpajakan yang berlaku.

Salah satu Visi dari Direktorat Jenderal Pajak adalah "Menjadi sebuah institusi pemerintah penghimpun pajak negara yang terbaik di wilayah Asia Tenggara". Sedangkan Misi Direktorat Jenderal Pajak adalah "Menyelenggarakan fungsi administrasi pajak dengan menerapkan UndangUndang Perpajakan dalam rangka membiayai penyelenggaraan negara demi kemakmuran rakyat".

Saat ini KPP mempunyai data Wajib Pajak dan Badan sebagai berikut :

Tabel 2. Data Wajib Pajak di KPP Pratama Jakarta Penjaringan

\begin{tabular}{|c|r|r|r|r|r|r|}
\hline s.d Tahun & WP Badan Terdaftar & WP OP Terdaftar & WP Badan Aktif & WP Badan NE & WP OP Aktif & WP OP NE \\
\hline 2013 & 6.519 & 46.199 & 3.625 & 2.894 & 31.124 & 15.075 \\
\hline 2014 & 6.893 & 50.308 & 3.996 & 2.897 & 35.223 & 15.085 \\
\hline 2015 & 7.267 & 55.539 & 4.369 & 2.898 & 40.444 & 15.095 \\
\hline 2016 & 7.605 & 62.107 & 4.705 & 2.900 & 47.009 & 15.098 \\
\hline 2017 & & & & & & \\
\hline
\end{tabular}

Sumber: KPP Pratama Jakarta Penjaringan, 2018

Berdasarkan data terlihat terjadi peningkatan setiap tahunnya, baik pada Wajib Pajak/ WP Badan maupun WP yang Orang Pribadi. Responden pada penelitian ini adalah 60 orang Adapun karakteristik responden penelitian menurut tingkat pendidikan formal dapat diketahui dari data berikut: 
Tabel 3. Karakteristik Responden Penelitian Menurut Tingkat Pendidikan Formal

\begin{tabular}{cc}
\hline Pendidikan & Jumlah responden (orang) \\
\hline SD & 0 \\
SLTA & 5 \\
Diploma & 16 \\
Sarjana & 25 \\
Pascasarjana & 14 \\
Jumlah & 60 \\
\hline
\end{tabular}

Sumber: Data primer diolah, 2018

Tabel 4. Karakteristik Responden Penelitian Menurut Jenis Kelamin

\begin{tabular}{cc}
\hline Jenis Kelamin & Jumlah responden (orang) \\
\hline Perempuan & 17 \\
Laki-laki & 43 \\
Jumlah & 60 \\
\hline
\end{tabular}

Sumber: Data primer diolah, 2018

Tabel di atas menunjukkan bahwa jumlah responden laki-laki lebih banyak dibandingkan dengan jumlah responden perempuan. Jumlah responden laki-laki melebihi 50\% dari total responden penelitian ini.

Tabel 5. Karakteristik Responden Penelitian Menurut Umur

\begin{tabular}{cc}
\hline Umur (tahun) & Jumlah responden (orang) \\
\hline $19-25$ & 20 \\
$26-32$ & 11 \\
$33-39$ & 13 \\
$40-46$ & 14 \\
$>47$ & 3 \\
Jumlah & 60 \\
\hline
\end{tabular}

Sumber : Kuesioner Penelitian 2018

Dari data yang tersaji terungkap bahwa sebagian besar responden penelitian berada pada usia 19-25 tahun. Responden lain menyebar antara 26-46 tahun. Responden yang berumur lebih dari 47 tahun berjumlah 3 orang.

\section{Uji Kualitas Data}

\section{Uji Validitas}

Uji validitas data dilakukan untuk mengukur apakah data yang diberikan pada kuisioner dapat dipercaya atau tidak serta dapat mewakili apa yang hendak diteliti. Dalam penelitian ini uji validitas data menggunakan rumus korelasi product moment. Sesuai dengan hasil perhitungan dengan bantuan program komputer SPSS for Windows Versi 24, diketahui tingkat validitas data penelitian sebagai berikut:

Tabel 6. Hasil Uji Validitas

\begin{tabular}{crr}
\hline Variabel & r-Hitung & Keterangan \\
\hline & $.750^{* *}$ & Valid \\
& $.709^{* *}$ & Valid \\
Variabel Pengampunan Pajak $\left(\mathrm{X}_{1}\right)$ & $.675^{* *}$ & Valid \\
& $.616^{* *}$ & Valid \\
$.536^{* *}$ & Valid \\
$.320^{*}$ & Valid \\
\hline
\end{tabular}




\begin{tabular}{clc}
\hline & $.600^{* *}$ & Valid \\
& $.552^{* *}$ & Valid \\
& $.506^{* *}$ & Valid \\
& $.587^{* *}$ & Valid \\
& $.389^{* *}$ & Valid \\
& $.765^{* *}$ & Valid \\
& $.626^{* *}$ & Valid \\
& $.643^{* *}$ & Valid \\
Variabel Kemudahan Administrasi Pajak & $.775^{* *}$ & Valid \\
$\left(\mathrm{X}_{2}\right)$ & $.739^{* *}$ & Valid \\
& $.641^{* *}$ & Valid \\
& $.781^{* *}$ & Valid \\
Variabel Tingkat Kepatuhan Wajib Pajak & $.741^{* *}$ & Valid \\
$(\mathrm{Y})$ & $.830^{* *}$ & Valid \\
& $.801^{* *}$ & Valid \\
& $.681^{* *}$ & Valid \\
\hline
\end{tabular}

Pada penelitian ini, $r$-Tabel $(n=60, k=j u m l a h$ semua variabel $=3$, sehingga $n-3=60-3=57$ ) pada tingkat signifikansi 0,05, menunjukkan $\mathrm{r}$-Tabel sebesar 0,25. Berikut hasil penghitungan r-Tabel. Pada Tabel berikut, seluruh nilai korelasi atau r-hitung setiap pertanyaan lebih dari nilai r-Tabel $(0,25)$. Hal ini berarti hasil pengujian validitas menunjukkan semua data valid.

\section{Uji Reliabilitas}

Uji Reliabilitas Variabel Pengampunan Pajak

Tabel 7. Hasil Uji Reliabilitas Variabel Pengampunan Pajak

\begin{tabular}{r|r}
\hline \multicolumn{2}{c}{ Reliability Statistics } \\
Cronbach's Alpha & N of Items \\
\hline .747 & 14 \\
\hline
\end{tabular}

Berdasarkan hasil uji reliabilitas untuk variabel skor data penelitian dengan menggunakan 381 orang responden, diperoleh nilai reliablitity statistic (cronbach alpha) variabel Pengampunan Pajak sebesar 0,784 atau di atas 0,5. Dengan demikian maka data hasil penelitian yang dilakukan adalah reliabel dan memenuhi syarat kualitas data yang baik.

Uji Reliabilitas Variabel Kemudahan Administrasi Pajak

Tabel 8. Hasil Uji Reliabilitas Variabel Kemudahan Administrasi Pajak

Reliability Statistics

\begin{tabular}{r|r} 
Cronbach's Alpha & N of Items \\
\hline .775 & 5 \\
\hline
\end{tabular}

Berdasarkan hasil uji reliabilitas untuk variabel skor data penelitian dengan menggunakan 60 orang responden, diperoleh nilai reliablitity statistic (cronbach alpha) variabel Pengampunan Pajak sebesar 0,775 atau di atas 0,5 . Dengan demikian maka data hasil penelitian yang dilakukan adalah reliabel dan memenuhi syarat kualitas data yang baik.

Uji Reliabilitas Variabel Tingkat Kepatuhan Wajib Pajak

Tabel 9. Hasil Uji Reliabilitas Variabel Tingkat Kepatuhan Wajib Pajak

\section{Reliability Statistics}

Cronbach's Alpha $\quad$ N of Items


Berdasarkan hasil uji reliabilitas untuk variabel skor data penelitian dengan menggunakan 60 orang responden, diperoleh nilai reliablitity statistic (cronbach alpha) variabel Pengampunan Pajak sebesar 0,797 atau di atas 0,5. Dengan demikian maka data hasil penelitian yang dilakukan adalah reliabel dan memenuhi syarat kualitas data yang baik.

\section{Uji Normalitas Data}

Tabel 10. One-Sample Kolmogorov-Smirnov Test

\begin{tabular}{llr|r|r} 
& & $\mathrm{x} 1$ & $\mathrm{x} 2$ & \multicolumn{1}{c}{$\mathrm{Y}$} \\
\hline $\mathrm{N}$ & & 60 & 60 & 60 \\
\hline Normal Parameters & & 70.83 & 17.85 & 22.85 \\
\hline \multirow{2}{*}{ Most Extreme Differences } & Mean & 6.165 & 1.849 & 2.090 \\
\cline { 2 - 5 } & Std. Deviation & .137 & .166 & .162 \\
\cline { 2 - 5 } & Absolute & .116 & .122 & .152 \\
\cline { 2 - 5 } & Positive & -.137 & -.166 & -.162 \\
\cline { 2 - 5 } & Negative & .137 & .166 & .162 \\
\hline Test Statistic & & $.051^{\mathrm{c}}$ & $.072^{\mathrm{c}}$ & $.068^{\mathrm{c}}$ \\
\hline Asymp. Sig. (2-tailed) & & & &
\end{tabular}

a. Test distribution is Normal.

b. Calculated from data.

c. Lilliefors Significance Correction.

Berdasarkan uji normalitas K-S/ Kolmogorov-Smirnov di atas, terlihat signifikansi dua arah $\mathrm{X}_{1}$ adalah 0,51 dan $X_{2}$ adalah 0,72 serta $Y$ adalah 0,68 . Nilai signifikan masing-masing variabel yang diuji tersebut $>0,05$, maka dapat disimpulkan data pada normal memiliki data yang sama dengan distribusi normal.

Uji Linieritas

Tabel 11 . Hasil Uji Linieritas Variabel Pengampunan Pajak $\left(\mathbf{X}_{1}\right)$ ANOVA Table

\begin{tabular}{|c|c|c|c|c|c|c|c|}
\hline & & & $\begin{array}{l}\text { Sum of } \\
\text { Squares }\end{array}$ & $\mathrm{df}$ & $\begin{array}{l}\text { Mean } \\
\text { Square }\end{array}$ & $\mathrm{F}$ & Sig. \\
\hline \multirow[t]{5}{*}{$y * x 1$} & \multirow[t]{3}{*}{ Between Groups } & (Combined) & 74.430 & 19 & 3.917 & .855 & .634 \\
\hline & & Linearity & 13.117 & 1 & 13.117 & $\begin{array}{r}2.86 \\
4 \\
\end{array}$ & .098 \\
\hline & & $\begin{array}{l}\text { Deviation } \\
\text { from } \\
\text { Linearity }\end{array}$ & 61.313 & 18 & 3.406 & .744 & .747 \\
\hline & Within Groups & & 183.220 & 40 & 4.581 & & \\
\hline & Total & & 257.650 & 59 & & & \\
\hline
\end{tabular}

Hasil penghitungan dengan menggunakan IBM SPSS 24, pada tabel di atas terlihat bahwa nilai signifikansi pada Deviation from Linearity sebesar 0,747 atau Sig>0,05. Nilai Deviation from Linearity menunjukkan seberapa jauh model persamaan regresi linier berganda menyimpang dari model linier. Nilai Deviation from Linearity yang memiliki Sig $>0,05$ (tidak signifikan), maka hal ini berarti terdapat hubungan yang linier antara variabel antara variabel Pengampunan Pajak $\left(\mathrm{X}_{1}\right)$ dengan variabel Tingkat Kepatuhan Wajib Pajak (Y). 
Tabel 12. Hasil Uji Linieritas Variabel Kemudahan Administrasi Pajak $\left(\mathrm{X}_{2}\right)$

\begin{tabular}{|c|c|c|c|c|c|c|c|}
\hline \multicolumn{8}{|c|}{ ANOVA Table } \\
\hline & & & $\begin{array}{l}\text { Sum of } \\
\text { Squares }\end{array}$ & $\mathrm{df}$ & $\begin{array}{l}\text { Mean } \\
\text { Square }\end{array}$ & $\mathrm{F}$ & Sig. \\
\hline \multirow[t]{5}{*}{$y * x 2$} & Between Groups & (Combined) & 25.967 & 7 & 3.710 & .833 & .565 \\
\hline & & Linearity & 8.195 & 1 & 8.195 & 1.839 & .181 \\
\hline & & $\begin{array}{l}\text { Deviation } \\
\text { from } \\
\text { Linearity }\end{array}$ & 17.772 & 6 & 2.962 & .665 & .678 \\
\hline & Within Groups & & 231.683 & 52 & 4.455 & & \\
\hline & Total & & 257.650 & 59 & & & \\
\hline
\end{tabular}

Hasil penghitungan dengan menggunakan IBM SPSS 24, pada tabel di atas terlihat bahwa nilai signifikansi pada Deviation from Linearity sebesar 0,678 atau Sig>0,05. Nilai Deviation from Linearity menunjukkan seberapa jauh model persamaan regresi linier berganda menyimpang dari model linier. Nilai Deviation from Linearity yang memiliki Sig $>0,05$ (tidak signifikan), maka hal ini berarti terdapat hubungan yang linier antara variabel Kemudahan Administrasi Pajak $\left(\mathrm{X}_{2}\right)$ dengan variabel Tingkat Kepatuhan Wajib Pajak (Y).

\section{Koefisien Korelasi dan Koefisien Determinasi}

Tabel 13. Hasil Penghitungan Koefisien Korelasi dan Koefisien Determininasi

Model Summary

\begin{tabular}{ll|r|r|r} 
Model & R & R Square & \multicolumn{1}{|c|}{$\begin{array}{c}\text { Adjusted R } \\
\text { Square }\end{array}$} & $\begin{array}{l}\text { Std. Error of } \\
\text { the Estimate }\end{array}$ \\
\hline 1 & $.427^{\mathrm{a}}$ & .32 & .28 & 2.070 \\
\hline
\end{tabular}

a. Predictors: (Constant), $\mathrm{x} 2, \mathrm{x} 1$

Hasil penghitungan tabel di atas menunjukkan nilai Koefisien Korelasi (R) sebesar 0,427. Nilai tersebut menunjukkan bahwa pengaruh variabel Pengampunan Pajak dan variabel Kemudahan Administrasi Pajak adalah berpengaruh cukup kuap terhadap Tingkat Kepatuhan Wajib Pajak.

Uji Regresi Linier Berganda

Tabel 14. Hasil Uji Regresi Linier Berganda

\section{Coefficients $^{\mathrm{a}}$}

\begin{tabular}{|c|c|c|c|c|c|c|}
\hline \multicolumn{7}{|c|}{ 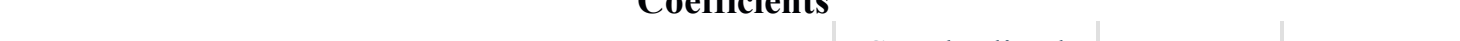 } \\
\hline \multirow[b]{2}{*}{ Model } & & \multicolumn{2}{|c|}{ Unstandardized Coefficients } & $\begin{array}{l}\text { Standardized } \\
\text { Coefficients }\end{array}$ & \multirow[b]{2}{*}{$\mathrm{t}$} & \multirow[b]{2}{*}{ Sig. } \\
\hline & & $\mathrm{B}$ & Std. Error & Beta & & \\
\hline \multirow[t]{3}{*}{1} & (Constant) & 17.303 & 3.166 & & 5.466 & .000 \\
\hline & $\mathrm{x} 1$ & .067 & .061 & .198 & 1.093 & .279 \\
\hline & $\mathrm{x} 2$ & .044 & .205 & .039 & .216 & .830 \\
\hline
\end{tabular}

a. Dependent Variable: y

Dari Tabel di atas diperoleh persamaan regresi linier berganda

$$
Y=17,303+0,067 X_{1}+0,044 X_{2}
$$

Keterangan:

$\mathrm{Y}=$ Tingkat Kepatuhan Wajib Pajak

$\mathrm{X}_{1}=$ Pengampunan Pajak

$\mathrm{X}_{2}=$ Kemudahan Administrasi Pajak 
Tabel 15. Uji Hipotesis $\mathrm{t}$

\begin{tabular}{|c|c|c|c|c|c|c|}
\hline \multicolumn{7}{|c|}{ Coefficients $^{\mathrm{a}}$} \\
\hline \multirow{3}{*}{\multicolumn{2}{|c|}{ Model }} & \multirow{2}{*}{\multicolumn{2}{|c|}{ Unstandardized Coefficients }} & \multirow{3}{*}{$\begin{array}{c}\text { Standardized } \\
\text { Coefficients } \\
\text { Beta } \\
\end{array}$} & \multirow[b]{3}{*}{$\mathrm{t}$} & \multirow[b]{3}{*}{ Sig. } \\
\hline & & & & & & \\
\hline & & $\mathrm{B}$ & Std. Error & & & \\
\hline \multirow[t]{3}{*}{1} & (Constant) & 17.303 & 3.166 & & 5.466 & .000 \\
\hline & $\mathrm{x} 1$ & .067 & .061 & .198 & 1.093 & .279 \\
\hline & $\mathrm{x} 2$ & .044 & .205 & .039 & .216 & .830 \\
\hline
\end{tabular}

a. Dependent Variable: y

Berdasarkan Tabel 12 menunjukkan variabel Pengampunan Pajak $\left(\mathrm{X}_{1}\right)$ mempunyai nilai t-hitung sebesar 1,093. Nilai t tabel yang merupakan standar untuk mengambil keputusan pada hipotesis dicari dengan menentukan $\mathrm{df}$. Nilai $\mathrm{df}=\mathrm{n}-\mathrm{k}, \mathrm{n}$ adalah jumlah responden dan $\mathrm{k}$ adalah jumlah semua variabel dalam penelitian ini $(\mathrm{df}=\mathrm{n}-\mathrm{k}=60-3=57)$, diperoleh nilai $\mathrm{t}$ tabel pada tingkat signifikansi 0,05 yaitu sebesar 2. Pada penelitian ini terdapat hipotesis:

$\mathrm{H}_{0}=$ Tidak terdapat pengaruh secara parsial antara Pengampunan Pajak terhadap Tingkat Kepatuhan Wajib Pajak.

$\mathrm{H}_{1}=$ Terdapat pengaruh secara parsial antara Pengampunan Pajak terhadap Tingkat Kepatuhan Wajib Pajak.

Hasil analisis menunjukkan nilai $\mathrm{t}_{\text {hitung }}<\mathrm{t}_{\text {tabel }}(1,093<2)$. Hal ini berarti $\mathrm{H}_{\mathrm{o}}$ diterima dan $\mathrm{H}_{1}$ ditolak, atau tidak terdapat pengaruh (secara parsial) antara Pengampunan Pajak terhadap Tingkat Kepatuhan Wajib Pajak.

Tabel 16. Hasil Uji F

\begin{tabular}{|c|c|c|c|c|c|c|}
\hline \multicolumn{7}{|c|}{ ANOVA $^{a}$} \\
\hline Model & & $\begin{array}{l}\text { Sum of } \\
\text { Squares }\end{array}$ & Df & Mean Square & $\mathrm{F}$ & Sig. \\
\hline \multirow[t]{3}{*}{1} & Regression & 23.316 & 2 & 8.658 & 4.553 & $.220^{\mathrm{b}}$ \\
\hline & Residual & 244.334 & 57 & 6.287 & & \\
\hline & Total & 257.650 & 59 & & & \\
\hline
\end{tabular}

a. Dependent Variable: y

b. Predictors: (Constant), $\mathrm{x} 2, \mathrm{x} 1$

Berdasarkan hasil perhitungan $\mathrm{F}$ hitung diperoleh nilai $\mathrm{F}$ sebesar 4,553 dengan signifikansi sebesar 0,000 lebih kecil dari 0,05. Nilai $\mathrm{F}$ tabel diperoleh dengan mencari N1 dan N2, dengan nilai $\mathrm{n}$ adalah jumlah responden (60), $\mathrm{k}$ adalah jumlah semua variabel (3). Dari nilai tersebut, diperoleh nilai $\mathrm{N} 1=3-1=2(\mathrm{df}=\mathrm{N} 1=\mathrm{k}-1)$ dan $\mathrm{N} 2=60-3=57(\mathrm{df}=\mathrm{N} 2=\mathrm{n}-\mathrm{k})$ adalah 3,16 , maka $\mathrm{F}$ hitung $>\mathrm{F}$ tabel $(4,552>$ $3,16)$. Pada penelitian ini terdapat hipotesis:

$\mathrm{H}_{0}=$ Tidak terdapat pengaruh secara bersama-sama/ simultan antara Pengampunan Pajak dan Kemudahan Administrasi Pajak terhadap Tingkat Kepatuhan Wajib Pajak.

$\mathrm{H}_{3}=$ Terdapat pengaruh secara bersama-sama/ simultan antara Pengampunan Pajak dan Kemudahan Administrasi Pajak terhadap Tingkat Kepatuhan Wajib Pajak.

Hal ini menunjukkan Ho ditolak dan $\mathrm{H}_{3}$ diterima atau variabel Pengampunan Pajak dan variabel Kemudahan Administrasi Pajak secara bersama-sama (secara simultan) berpengaruh terhadap Tingkat Kepatuhan Wajib Pajak.

\section{KESIMPULAN} adalah:

Berdasarkan tujuan penelitan dan hasil penelitian yang dilakukan, kesimpulan dari penelitian ini

Berdasarkan penelitian, menunjukkan variabel Pengampunan Pajak (X1) mempunyai nilai thitung sebesar 1,093. Nilai t tabel yang merupakan standar untuk mengambil keputusan pada hipotesis 
dicari dengan menentukan df. Nilai $\mathrm{df}=\mathrm{n}-\mathrm{k}, \mathrm{n}$ adalah jumlah responden dan $\mathrm{k}$ adalah jumlah semua variabel dalam penelitian ini $(\mathrm{df}=\mathrm{n}-\mathrm{k}=60-3=57)$, diperoleh nilai $\mathrm{t}$ tabel pada tingkat signifikansi 0,05 yaitu sebesar 2. Pada penelitian ini terdapat hipotesis:

$\mathrm{H}_{0}=$ Tidak terdapat pengaruh secara parsial antara Pengampunan Pajak terhadap Tingkat Kepatuhan Wajib Pajak.

$\mathrm{H}_{1}=$ Terdapat pengaruh secara parsial antara Pengampunan Pajak terhadap Tingkat Kepatuhan Wajib Pajak.

Hasil analisis menunjukkan nilai $t$ hitung $<\mathrm{t}$ tabel $(1,093<2)$. Hal ini berarti Ho diterima dan H1 ditolak, atau tidak terdapat pengaruh (secara parsial) antara Pengampunan Pajak terhadap Tingkat Kepatuhan Wajib Pajak..

Pada hasil penelitian, variabel Kemudahan Administrasi Pajak mempunyai nilai t sebesar 0,216 . Nilai $\mathrm{df}=\mathrm{n}-\mathrm{k}, \mathrm{n}$ adalah jumlah responden dan $\mathrm{k}$ adalah jumlah semua variabel dalam penelitian ini $(\mathrm{df}=\mathrm{n}-\mathrm{k}=60-3=57)$, diperoleh nilai $\mathrm{t}$ tabel pada tingkat signifikansi 0,05 yaitu sebesar Pada penelitian ini terdapat hipotesis:

$\mathrm{H}_{0}=$ Tidak terdapat pengaruh secara parsial antara Kemudahan Administrasi Pajak terhadap Tingkat Kepatuhan Wajib Pajak.

$\mathrm{H}_{2}=$ Terdapat pengaruh secara parsial antara Kemudahan Administrasi Pajak terhadap Tingkat Kepatuhan Wajib Pajak.

Dari hasil analisis data menunjukkan $\mathrm{t}_{\text {hitung }}<\mathrm{t}_{\text {tabel}}$, yaitu $0,216<2$ pada taraf signifikansi sebesar 0,05 . Hal ini berarti $\mathrm{H}_{\mathrm{o}}$ diterima dan $\mathrm{H}_{2}$ ditolak.

Artinya, bahwa tidak terdapat pengaruh (secara parsial) antara variabel Kemudahan Administrasi Pajak terhadap Tingkat Kepatuhan Wajib Pajak..

Besarnya pengaruh yang ditunjukkan oleh Koefisien Korelasi (R) antara variabel Tax Amnesty dan Kemudahan Administrasi Perpajakan secara bersama-sama (secara simultan) adalah berpengaruh cukup kuat terhadap Kepatuhan Wajib Pajak Orang Pribadi KPP Pratama Jakarta Penjaringan. Sedangkan koefisien determinasi (adjusted $R^{2}$ ) menunjukkan nilai adjusted $R^{2}=0,28$. Artinya variabel Pengampunan Pajak $\left(\mathrm{X}_{1}\right)$ dan Kemudahan Administrasi Perpajakan $\left(\mathrm{X}_{2}\right)$ dapat menerangkan atau menjelaskan Kepatuhan Wajib Pajak Orang Pribadi KPP Pratama Jakarta Penjaringan (Y) sebesar $28 \%$, sisanya sebesar $72 \%$ dipengaruhi oleh variabel lain yang tidak termasuk dalam model atau persamaan pada penelitian ini.

\section{SARAN}

Berdasarkan hasil penelitian, berikut ini adalah saran untuk meningkatkan Kepatuhan Wajib Pajak Orang Pribadi :

Untuk meningkatkan Kepatuhan Wajib Pajak dalam konsep kemauan membayar pajak (Willingness to Pay Tax) dapat dikembangkan melalui 2 (dua) subkonsep yaitu konsep kemauan membayar pajak dan konsep pajak. Kemauan dalam membayar pajak dapat dipengaruhi oleh faktorfaktor, yaitu kondisi sistem administrasi perpajakan suatu negara, pelayanan pada Wajib Pajak, penegakan hukum perpajakan dan tarif pajak (Devano dan Rahayu, 2006).

Benno Torgler \& Cristoph A. Schaltegger yang dikutip Darussalam dalam Inside review, Amnesti Pajak sebaiknya diberikan hanya sekali saja dalam suatu generasi. Apabila Amnesti Pajak yang diberikan berkali-kali dapat menyebabkan Wajib Pajak akan selalu menunggu Program Amnesti Pajak berikutnya dan sehingga wajib pajak tidak menjalankan kewajiban pajaknya dengan benar dan tepat waktu. Jika pemerintah akan memberikan Tax Amnesty, maka tidak boleh ada isu tentang Program Pengampunan Pajak selanjutnya.

Sosialisasi yang intensif dari KPP Jakarta Penjaringan agar masyarakat, khususnya Wajib Pajak dapat memiliki pengetahuan administrasi pajak yang baik.

\section{DAFTAR PUSTAKA}

\section{A. Program Studi Ilmu Administrasi}

Dewi, Irra Chrisyanti. 2011. Pengantar Ilmu Administrasi. Jakarta: PT Prestasi. 
Keban, T. Yeremias. 2004. Enam Dimensi Strategis Administrasi Publik, Konsep,. Teori dan Isu. Yogyakarta: Gava Media.

Lubis, Solly. 2007. Ilmu Negara. Bandung: Mandar Maju.

Nawawi, Ismail. 2009. Perilaku Administrasi (Kajian, Teori dan Pengantar Praktik). Surabaya: CV Media Putra.

Tachjan. 2008. Implementasi Kebijakan Publik. Bandung: Asosiasi Ilmu Politik Indonesia (AIPI).

\section{B. Kekhususan Perpajakan.}

Darrussalam, Danny. 2015. Manfaatkan Pengampunan Pajak: Pahami dan Manfaatkan Reinventing Policy. Inside Tax Edisi 31.

Devano, Sony dan Siti Kurnia Rahayu. 2006. Perpajakan Konsep, Teori dan Isu. Jakarta: Kencana Prenada Media Group.

Gunadi. 2013. Panduan Komprehensif Pajak Penghasilan. Jakarta: Bee Media.

Hardika, N. Sentosa. 2006. Pengaruh Lingkungan dan Moral Wajib Pajak Terhadap Sikap dan Kepatuhan Wajib Pajak Pada Hotel Berbintang di Provinsi Bali. (Disertasi). Surabaya: Universitas Airlangga.

Melisari, Lisa Adha. 2008. Pengaruh Penerapan Sistem Monitoring Pelaporan Pembayaran Pajak (MP3) dan Profesionalisme Terhadap Kepatuhan Wajib Pajak. (Skripsi). Jakarta: UIN.

Muttaqin, Zaenal. 2012. Tax Amnesty Di Indonesia. Jakarta: Refika Aditama.

Nurmantu, Safri. 2005. Pengantar Perpajakan. Jakarta: Granit.

Pandiangan, Liberti. 2008. Modernisasi dan Reformasi Pelayanan Perpajakan Berdasarkan UndangUndang Terbaru. Jakarta: PT Elex Media Komputindo.

Rahayu, Kurnia. 2009. Perpajakan Indonesia: Konsep dan Aspek Formal. Yogyakarta: Graha Ilmu.

------. 2010. Perpajakan Indonesia: Konsep dan Aspek Formal. Yogyakarta: Graha Ilmu.

Resmi, Siti. 2008. Perpajakan:Teori dan Kasus Edisi 4, Jakarta: Salemba Empat.

Satriyo, A. 2007. Pengaruh Reformasi Administrasi Perpajakan Terhadap Kepatuhan Wajib Pajak Pada KPP Pratama Jakarta Setiabudi. (Skripsi). Jakarta: Universitas Pembangunan Nasional Veteran.

Silitonga, Erwin. 2006. Ekonomi Bawah Tanah, Pengampunan Pajak, dan Referendum. (Majalah Berita Pajak, Nomor. 1516 Tahun XXXVIII April 2006). Jakarta

Soemarso S.R, 2007. Perpajakan Pendekatan Komprehensif. Jakarta: Salemba. Empat.

Waluyo. 2007. Perpajakan Indonesia, Buku 1 Edisi 7. Jakarta: Salemba Empat.

Widaningrum, Dwi. 2007. Identifikasi Kemampuan dan Kemauan Membayar Masyarakat Berpenghasilan Menengah Rendah. www.sappk.tb.ac.id/ppk/images/stories/pdf/ringkasan_dwi.pdf. Diunduh tanggal 2 Desember 2017.

Zain, Mohammad. 2008. Manajemen Perpajakan. Jakarta: Salemba Empat.

------. 2004. Manajemen Perpajakan. Jakarta: Salemba Empat.

\section{Metode Penelitian.}

Kuncoro. 2001. Metode Penelitian Kuantitatif. Yogyakarta: UPP AMP YKPM.

Neuman, W.L. 2006. Social Research Methods: Qualitative and Quantitative Approach, 6th ed. Boston: Allyn and Bacon.

Singarimbun, Masri. 1995. Metode Penelitian Survey. Jakarta: LP3ES. 
Arikunto S, 2006. Prosedur Penelitian Suatu Pendekatan Praktik, Ed Revisi VI. Jakarta: PT Rineka Cipta.

Indriantoro, Nur. 1999. Metodologi Penelitian dan. Bisnis. Yogyakarta: BPFE.

Sugiyono. 2005. Metode Penelitian Administrasi. Bandung: Alfabeta.

Djaali. 2008. Skala likert. Jakarta: Pustaka Utama.

\section{Jurnal}

Adrian, Sawyer. 2006. Targeting Amnesties at Ingrained Evasion - a New Zealand Initiative Warranting Wilder Consideration?, Journal Taxation and Business Law University of Cantebury.

Ayu, Viega dan Fidiana. 2017. Pengaruh Tax Amnesty, Pengetahuan Perpajakan, Dan Pelayanan Fiskus Terhadap Kepatuhan Wajib Pajak Pada Kantor Pelayanan Pajak Pratama Surabaya Tegalsari. Surabaya: Jurnal Ilmu dan Riset Akuntansi Sekolah Tinggi Ilmu Ekonomi Indonesia, Volume 6 No 2 Februari 2017.

Fatih, Osman dan Eren. 2011. Tax Amnesty with Effects and Effecting Aspects: TaxCompliance, Tax Audits and Enforcements Around; The Turkish Case. Turki: International Journal of Business and Social Science Volume 2 No 7 April 2011.

Helhel dan Ahmed. 2014. Factors Affecting Tax Attitudes and Tax Compliance:A Survey Study in Yemen. Yaman: European Journal of Business and Management Vol 6 No 22 Tahun 2014.

Puspareni, Diah et al. 2017. Pengaruh Tax Amnesty, Pertumbuhan Ekonomi, Kepatuhan Wajib Pajak, Dan Transformasi Kelembagaan Direktorat Jenderal Pajak Terhadap Penerimaan Pajak Tahun 2015 Di Kantor Pelayanan Pajak Pratama Singaraja. Bali: e-journal S1 Ak Universitas Pendidikan Ganesha, Volume 7 No 1 Tahun 2017.

Santoso, W. 2008. Analisis Risiko Ketidakpatuhan Wajib Pajak sebagai Dasar Peningkatan Kepatuhan Wajib Pajak (Penelitian terhadap Wajib Pajak Badan di Indonesia). Jurnal Keuangan Publik. Vol. 5, No. 1.

Yusril, Muhammad et al. 2015. Pengaruh Administrasi Perpajakan, kualitas layanan fiskus, terhadap perilaku Wajib Pajak dan kepatuhan Wajib Pajak pada Kantor Pelayanan Pajak Malang Selatan. Malang: e-journal Fakultas Ilmu Administrasi Universitas Brawijaya, Volume 9 No 2 Tahun 2015.

\section{Dokumen}

Surat Edaran SE-01/PJ.9/20 tentang Pengawasan Penyampaian SPT Tahunan.

Surat Edaran SE-002/PJ/2008 tentang Tata Cara penetapan Wajib Pajak dengan kriteria tertentu. 